\title{
Pain and associated symptoms: comparison between fibromyalgia and temporomandibular disorder
}

\author{
Dor e sintomas associados: comparação entre fibromialgia e disfunção temporomandibular
}

Sandra Cristina Andradeㄹ, Renata Cavalcanti de Souza², Euclécia Lopes Queiroz Silva², Rodrigo Pegado de Abreu Freitas³ ${ }^{3}$ Lilian Lira Lisboa ${ }^{1}$, Hárrison de Almeida Dantas ${ }^{4}$

DOI 10.5935/1806-0013.20160072

\section{ABSTRACT}

BACKGROUND AND OBJECTIVES: Fibromyalgia has multivariate symptoms, also affecting temporomandibular region. This study aimed at comparing facial signs and symptoms of females with fibromyalgia and females with temporomandibular disorder.

METHODS: This is a crossover study with 61 females divided in two groups: fibromyalgia group (31) and temporomandibular disorder group (30). Evaluated variables in all patients were: pain intensity in temporomandibular joint by means of visual analog scale, report of pain or discomfort during daily activities (mouth opening/closing, during meals, when talking), presence of joint noises (clicking and popping), dizziness, tinnitus, headache and mouth opening capacity. Variables were compared by unpaired $t$ and Chi-square tests.

RESULTS: Facial pain was reported by $100 \%$ of studied patients with no difference in intensity among fibromyalgia and temporomandibular disorder groups $(\mathrm{p}=0.2170)$. Fibromyalgia group has reported more pain during daily life activities as compared to temporomandibular disorder group $(\mathrm{p}<0.0001)$. With regard to joint noises, there has been more right temporomandibular joint clicking $(\mathrm{p}=0.006)$ in the temporomandibular disorder group. Fibromyalgia group patients have higher percentage of signs and symptoms associated to temporomandibular disorder, such as dizziness, tinnitus and headache $(\mathrm{p}<0.000)$.

CONCLUSION: Fibromyalgia patients have clinical signs and symptoms similar to those found in temporomandibular disorder patients, being pain, discomfort during daily activities, tinnitus, hum and headache more exacerbated in the fibromyalgia group. Keywords: Fibromyalgia, Pain, Temporomandibular disorder.

1. Universidade Federal do Rio Grande do Norte, Departamento de Fisioterapia, Natal, $\mathrm{RN}$, Brasil.

2. Universidade Potiguar, Curso de Fisioterapia, Natal, RN, Brasil.

3. Universidade Federal do Rio Grande do Norte, Faculdade de Ciências da Saúde do Trairí, Santa Cruz, RN, Brasil.

4. Universidade Potiguar, Curso de Odontologia, Natal, RN, Brasil.

Submitted in April 29, 2016.

Accepted for publication in August 03, 2016.

Conflict of interests: none - Sponsoring sources: none.

Correspondence to:

Campus Universitário Lagoa Nova

59078-970 Natal, RN, Brasil.

E-mail: rodrigopegado@gmail.com

(C) Sociedade Brasileira para o Estudo da Dor

\section{RESUMO}

JUSTIFICATIVA E OBJETIVOS: A fibromialgia apresenta sintomas multivariados acometendo também a região temporomandibular. O objetivo deste estudo foi comparar os sinais e sintomas faciais de mulheres com fibromialgia e mulheres com disfunção temporomandibular.

METODOS: Foi realizado um estudo de corte transversal com 61 mulheres, divididas em dois grupos: grupo fibromialgia (31) e grupo disfunção temporomandibular (30). As variáveis avaliadas em todas as pacientes foram: intensidade da dor na articulação temporomandibular por meio da escala visual analógica, relato de dor ou desconforto nas atividades diárias (abrir/fechar a boca, durante a alimentação, ao falar), presença de ruídos articulares (estalo e crepitação), tontura, zumbido, cefaleia e capacidade na abertura de boca. As variáveis foram comparadas pelos testes $t$ não pareado e Qui-quadrado.

RESULTADOS: Dor na região facial foi relatada por $100 \%$ das pacientes do estudo, não havendo diferença da intensidade entre os grupos fibromialgia e disfunção temporomandibular $(\mathrm{p}=0,2170)$. O grupo fibromialgia relatou maior percentual de dor nas atividades de vida diária quando comparado ao grupo disfunção temporomandibular $(\mathrm{p}<0,0001)$. Quanto aos ruídos articulares observou-se maior percentual para crepitação da articulação temporomandibular direita $(p=0,006)$ do grupo disfunção temporomandibular. As pacientes do grupo fibromialgia apresentaram maior percentual dos sinais e sintomas associados à disfunção temporomandibular como tontura, zumbido e cefaleia $(\mathrm{p}<0,000)$.

CONCLUSÃO: Pacientes com fibromialgia possuem sinais e sintomas clínicos semelhantes aos encontrados em pacientes com disfunção temporomandibular, sendo a dor, desconforto nas atividades diárias, tontura, zumbido e cefaleia mais exacerbada no grupo fibromialgia.

Descritores: Disfunção temporomandibular, Dor, Fibromialgia.

\section{INTRODUCTION}

Temporomandibular disorder (TMD) is a collective health problem affecting 5 to $12 \%$ of the population ${ }^{1}$. TMD is a generic term used to name different clinical conditions affecting masticatory muscles, temporomandibular joint (TMJ) and associated structures, taking into consideration arthrogenic and myogenic inter-relation, as well as nervous system influence and biopsychosocial interaction ${ }^{1,2}$. 
These disorders typically course with recurrence and chronicity, being characterized by facial pain in TMJ joint and/ or masticatory muscles, noises at mouth opening and/ or closing, jaw movement limitation or shift, jaw locking, facial muscles spasm, headaches and hearing disorders ${ }^{3,4}$. Some patients may also have mood disorders, such as anxiety, depression and somatization ${ }^{5,6}$.

In some cases, facial pain may be expression of different musculoskeletal disease, such as fibromyalgia (FM), where facial pain is just one aspect of the disorder involving all body muscles ${ }^{7,8}$. Previous studies have shown high frequency of TMD in FM patients, which might have influenced the review of diagnostic criteria for the disease ${ }^{9-13}$. Criteria proposed in 2010 by the American College of Rheumatology (ACR) take into consideration other symptoms in addition to diffuse pain to the detriment of tender points palpation ${ }^{14}$. With these new criteria, it is necessary to investigate painful areas to establish a generalized pain index taking into consideration jaw pain.

TMD may exacerbate negative FM impact since such disorders often lead to changes in sleep quality and emotional status, with consequent decrease in functional capacity and quality of life $\mathrm{e}^{15-18}$.

Although there are reports of high TMD frequency in FM patients, a small number of studies have compared the severity of these manifestations in patients with TMD and without FM.

\section{METHODS}

A crossover study was carried out with FM female patients aged between 35 and 65 years, in the period from January to June 2010, in the Clínica Escola de Fisioterapia, Universidade Potiguar (UNP), Natal, Brazil.

Sample was made up of 61 females with facial pain complaints, of whom 31 were referred by rheumatologists with diagnosis of FM according to 1990 classification criteria of the American College of Rheumatology (ACR ${ }^{19}$ and became the FM group. TMD group was made up of 30 individuals referred by dentists with Research Diagnostic Criteria for Temporomandibular Disorders (RDC-TMD Axis I) ${ }^{20,21}$. Exclusion criteria for both groups were being illiterate, having suffered accident and/or surgical intervention in the face, having been submitted to ear surgery, having suffered TMJ luxation, presence of autoimmune rheumatologic disease, chronic otitis or mental deficiency impairing the evaluation process.

Initially, all participants were informed about study objectives and those agreeing to participate have signed the Free and Informed Consent Term (FICT). Data were collected in the evaluation room, Clínica Escola de Fisioterapia, UNP. All patients were individually evaluated, with mean duration of 40 minutes. Patients have filled an evaluation card with socio-demographic (age, gender, marital status and education level) and clinical data.

Clinical data were: disease duration; presence and in- tensity of TMJ pain, measured by the visual analog scale (VAS), varying from zero to 10 , being zero no pain and 10 unbearable pain; pain at mouth opening and closing, eating and talking. Physical TMJ exam has evaluated maximum (forced) and normal mouth opening, presence of joint noises (cracks or crackles) at mouth opening and closing, evaluated by auscultation with stethoscope positioned on TMJ region. Participants were also asked about the presence of dizziness, tinnitus and headache.

\section{Statistical analysis}

Descriptive data interpretation was performed with quantitative variables described in central trend and variability values and categorical variables shown in absolute and relative frequency. Sample values normality was checked with Shapiro-Wilk test. Unpaired Student $t$ test was used for intergroup analysis. Statistical significance for all analyses was $\mathrm{p}<0.05$. Data were analyzed with statistical software SPSS (version 19.0).

This study was approved by the Research Ethics Committee, UNP number 306/2009 (CAAE 0285.0.052.000-09).

\section{RESULTS}

Participated in the study 61 females, being 31 of FM group and 30 of TMD group. Mean age of FM group was 53.6 \pm 9.7 years and of TMD group $47.30 \pm 9.1$ years with statistically significant difference between groups $(\mathrm{p}=0.0194)$. In both FM and TMD groups, most were married, with 45.2 and $66.7 \%$, respectively. However in education level evaluation, it was observed that FM group patients had higher education level as compared to the TMD group (Table 1).

With regard to clinical data, all patients have reported pain in at least one TMJ. As to facial pain intensity, it was observed that FM group patients had higher intensity as compared to TMD group, with values of $6.2 \pm 2.4$ and $5.4 \pm 2.4$, respectively, however without difference between groups $(\mathrm{p}=0.2170)$. With regard to pain during daily activities, FM

Table 1. Distribution of socio-demographic data of studied groups

\begin{tabular}{lccc}
\hline Variables & $\begin{array}{c}\text { FM } \\
(\mathrm{n}=31)\end{array}$ & $\begin{array}{c}\text { TMD } \\
(\mathrm{n}=30)\end{array}$ & p value \\
\hline Age (mean+SD, years) & $53.6 \pm 9.7$ & $47.3 \pm 9.1$ & $0.0194^{*}$ \\
$\begin{array}{l}\text { Marital status, } \mathrm{n}(\%) \\
\quad \text { Single }\end{array}$ & $10(32.3)$ & $5(16.7)$ & - \\
$\quad$ Married & $14(45.2)$ & $20(66.7)$ & - \\
$\quad$ Divorced & $6(19.4)$ & $3(10.0)$ & - \\
$\quad$ Widow & $1(3.2)$ & $2(6.7)$ & - \\
Education, $n(\%)$ & & & - \\
$\quad$ Elementary school & $6(19.4)$ & $17(56.7)$ & - \\
High school & $21(67.7)$ & $7(23.3)$ & - \\
$\quad$ College & $4(12.9)$ & $6(20.0)$ & - \\
\hline
\end{tabular}

*Value of unpaired Student $t$ test

$\mathrm{FM}=$ fibromyalgia group, $\mathrm{TMD}$ = temporomandibular disorder group. 
Table 2. Distribution and analysis of temporomandibular joint clinical variables for both groups

\begin{tabular}{|c|c|c|c|}
\hline Variables & $\begin{array}{c}\text { FM } \\
\text { (31 patients) }\end{array}$ & $\begin{array}{c}\text { TMD } \\
\text { (30 patients) }\end{array}$ & $p$ value \\
\hline TMD pain intensity (mean $\pm S D$ ) & $6.2( \pm 6.4)$ & $5.5( \pm 2.4)$ & 0.2170 \\
\hline Maximum mouth opening (mean $\pm S D)$ & $44.9( \pm 7.34)$ & $42.6( \pm-6.52)$ & 0.2072 \\
\hline Normal mouth opening $($ mean $\pm S D, m m)$ & $30.2( \pm 11.1)$ & $33.2( \pm 9.2)$ & 0.2595 \\
\hline \multicolumn{4}{|l|}{ Pain or discomfort at daily activities (n, \%) } \\
\hline Mouth opening/closing & $14(45.2)$ & $7(23.3)$ & $0.0001^{\mp}$ \\
\hline Talking & $25(80.6)$ & $18(60.0)$ & $0.0001^{\mp}$ \\
\hline \multicolumn{4}{|l|}{ Joint noise (auscultation) (n \%) } \\
\hline Crack right TMJ opening & $20(64.5)$ & $24(80.0)$ & 0.178 \\
\hline Crack left TMJ opening & $19(61.3)$ & $20(66.7)$ & 0.662 \\
\hline Left TMJ crackle & $6(19.4 \%)$ & $11(36.7 \%)$ & 0.132 \\
\hline \multicolumn{4}{|l|}{ Associated signs and symptoms, (n, \%) } \\
\hline Dizziness & $24(77.4 \%)$ & $19(63.3 \%)$ & $0.0001^{\mp}$ \\
\hline Tinnitus & $27(87.1 \%)$ & $20(66.7 \%)$ & $0.0001^{\mp}$ \\
\hline headache & $25(80.6 \%)$ & $20(66.7 \%)$ & $0.0001^{\mp}$ \\
\hline
\end{tabular}

${ }^{\mp} p<0.05$ in Chi-square test.

$\mathrm{TMJ}$ = temporomandibular joint; FM = fibromyalgia group; TMD = temporomandibular disorder group.

group had higher percentages as compared to TMD group in all evaluated items: mouth opening/closing $45.2 \%$ and $23.3 \%$; during food intake $54.8 \%$ and $40 \%$ and when talking $80.6 \%$ and $60.0 \%$, respectively.

As to mouth opening amplitude, it was observed that FM group patients had lower mouth opening without, however, difference between groups ( $\mathrm{p}=0.2595)$. In maximum mouth opening evaluation, FM group participants had higher opening as compared to TMD group, again without statistically significant difference between groups $(\mathrm{p}=0.2072)$ (Table 2). At auscultation, TMD group had higher prevalence of all evaluated joint noises (crackles and cracks), except for left TMJ closing crack where FM group had higher prevalence. However, there has only been statistically significant difference in right TMJ crackle $(\mathrm{p}<0.006)$.

With regard to associated signs and symptoms, it was observed that FM group patients had higher percentage as compared to TMD group patients in all evaluated symptoms (dizziness, tinnitus and headache), with statistically significant difference between groups (Table 2).

\section{DISCUSSION}

Previous studies were carried out in the attempt to understand the connection between TMD and FM, having most observed that a large part of FM patients had characteristic TMD signs and symptoms. However, few TMD patients were diagnosed with fibromyalgia9.10.12.22. In light of the results, four theoretical models try to explain the connection between FM and TMD: (1) decreased pain threshold in FM is responsible for facial musculoskeletal pain and, in this case, FM is the predominant problem predisposing to TMD; (2) FM and TMD are associated to primary behavioral changes (psychological or psychiatric), that is, have no direct causal relationship, but appear as consequence of some mental health abnormality; (3) anguish and anxiety feeling in FM patients leads to more medical consultations, thus helping the diagnosis; (4) all painful disorders are associated to increased FM prevalence ${ }^{23}$.

Our study has observed that FM group patients had more severe facial pain as compared to the TMD group, as well as a larger number of females with FM have reported pain at mouth opening and closing, eating and talking. It is suggested that more severe pain in FM group, as well as higher percentages of facial pain report during daily activities, may be due to disease pathophysiology itself, where there is central amplification and increased general sensitivity to pain and patients may present hyperalgesia (increased response to normally painful stimuli) and/or allodynia (painful response to painless stimuli) ${ }^{24}$. Previous studies have shown that in FM patients, painful response may be reached with painful stimuli much lower than necessary ${ }^{25,26}$.

All patients from both groups had decreased normal mouth opening without significant difference between groups. However, FM group patients had lower mouth opening as 
compared to TMD group, fact also described by GarcíaMoya et al. ${ }^{27}$. However, forced mouth opening evaluation has shown that FM group had higher mouth opening as compared to TMD group. It is suggested that, in this type of evaluation, biomechanical disorders found in FM do not affect movement amplitude, which is not true for the TMD group where arthrokinematic and osteokinematic disorders prevent mouth opening ${ }^{28}$.

This result might be directly related to the origin of pain in both groups. In the TMD group without FM, pain may be induced by joint wear processes, inflammatory process, occlusion abnormalities, facial trauma and disc displacement. These factors associated to facial muscles spasms, especially the masseter muscle, may contribute to mouth opening difficulty ${ }^{11,29}$. On the other hand, studies have shown that the most common TMD diagnosis in fibromyalgia is myofascial (RDC/TMD Axis I subgroup I) and that most frequent signs are mouth opening limitation, noises at mouth opening and closing, masseter and posterior digastric muscles pain, TMJ pain and headache $e^{10,30}$.

Our study has observed, at TMJ auscultation, cracks or crackles during mouth opening and/or closing, with higher percentage in the TMD group with more frequent joint noises being cracks or crackles. Joint noises may be caused by changes in condyle position, which may induce disc displacement and generate functional asynchrony between condyle and $\operatorname{disc}^{31}$.

With regard to other signs and symptoms often reported both by FM and TMD patients, such as headache, dizziness and tinnitus, FM group patients had higher frequency of all evaluated symptoms as compared to TMD group patients. Previous studies have shown that both FM and TMD patients had high index of such manifestations, however, in our study, we have found higher percentages than those reported in the literature ${ }^{32}$. In a different study, headache was the most frequent symptom among TMD patients $(34.39 \%)^{33}$. It is suggested that the high prevalence of headache in both groups is related to TMJ connection with cervical and temporal muscles, ligaments and fascias, forming a functional complex called cranio-cervico-mandibular system. Authors have reported that masseter muscle is hyperactivated both in FM and in TMD patients ${ }^{34}$.

\section{CONCLUSION}

FM group had clinical signs and symptoms similar to those found in the TMD group, being pain, discomfort during daily activities, dizziness, tinnitus and headache more exacerbated in the FM group.

Although being different clinical entities, FM and TMD may have common signs and symptoms or be associated. However, the reason for pain is different due to pathophysiological peculiarities of each disease. We emphasize the importance of clinical investigation and multiprofessional action aiming at preventing and/or minimizing TMD symptoms.

\section{REFERENCES}

1. Schiffman E, Ohrbach R, Truelove E, Look J, Anderson G, Goulet JP, et al. Diagnostic Criteria for Temporomandibular Disorders (DC/TMD) for Clinical and Research Applications: recommendations of the International RDC/TMD Consortium Network and Orofacial Pain Special Interest Group. J Oral Facial Pain Headache. 2014;28(1):6-27.

2. Truelove EL, Sommers EE, LeResche L, Dworkin SF, Von Korff M. Clinical diagnostic criteria for TMD. New classification permits multiple diagnoses. J Am Dent Assoc. 1992;123(4):47-54.

3. Costa AL, D'Abreu A, Cendes F. Temporomandibular joint internal derangement: association with headache, joint effusion, bruxism, and joint pain. J Contemp Dent Pract. 2008;9(6):9-16.

4. Nassri LF, Abdala N, Szejnfeld J, Nassri MR. Análise comparativa entre os achados de eletromiografia do músculo facial masseter em indivíduos com e sem disfunção temporomandibular: parte I. RSBO. 2009;6(4):393-400.

5. Dıraçoğlu D, Yıldırım NK, Saral İ, Özkan M, Karan A, Özkan S, Aksoy C. Temporomandibular dysfunction and risk factors for anxiety and depression. J Back Musculoskelet Rehabil. 2015,30(1):1-5.

6. Reiter S, Emodi-Perlman A, Goldsmith C, Friedman-Rubin P, Winocur E. Comorbidity between depression and anxiety in patients with temporomandibular disorders according to the research diagnostic criteria for temporomandibular disorders. J Oral Facial Pain Headache. 2015;29(2):135-43.

7. Fujarra FJ, Kaziyama HH, Siqueira SR, Yeng LT, Camparis CM, Teixeira MJ, Siqueira JT. Temporomandibular disorders in fibromyalgia patients: are there different pain onsets? Arq Neuropsiquiatr. 2016;74(3):195-200.

8. Moldofsky HK. Disordered sleep in fibromyalgia and related myofascial facial pain conditions. Dent Clin North Am. 2001;45(4):701-13.

9. Manfredini D, Tognini F, Montagnani G, Bazzichi L, Bombardieri S, Bosco M. Comparison of masticatory dysfunction in temporomandibular disorders and fibromyalgia. Minerva Stomatol. 2004;53(11-12):641-50.

10. Fraga BP, Santos EB, Farias Neto JP, Macieira JC, Quintans LJ, Onofre AS, et al. Signs and symptoms of temporomandibular dysfunction in fibromyalgic patients. J Craniofac Surg. 2012;23(2):615-8

11. Leblebici B, Pektaş ZO, Ortancil O, Hürcan EC, Bagis S, Akman MN. Coexistence of fibromyalgia, temporomandibular disorder, and masticatory myofascial pain syndromes. Rheumatol Int. 2007;27(6):541-4.

12. Plesh O, Wolfe F, Lane N. The relationship between fibromyalgia and temporomandibular disorders: prevalence and symptom severity. J Rheumatol. 1996;23(11):1948-52..

13. Rhodus NL, Fricton J, Carlson P, Messner R. Oral symptoms associated with fibromyalgia syndrome. J Rheumatol. 2003; 30(8):1841-5.

14. Wolfe F, Clauw DJ, Fitzcharles MA, Goldenberg DL, Häuser W, Katz RS, et al. Fibromyalgia criteria and severity scales for clinical and epidemiological studies: a modificationof the ACR Preliminary Diagnostic Criteria for Fibromyalgia. J Rheumatol. 2011;38(6):1113-22.

15. Smith MT, Wickwire EM, Grace EG, Edwards RR, Buenaver LF, Peterson S. Sleep disorders and their association with laboratory pain sensitivity in temporomandibular joint disorder. Sleep. 2009;32(6):779-90.

16. John MT, Reissmann DR, Schierz O, Wassell RW. Oral health-related quality of life in patients with temporomandibular disorders. J Orofac Pain. 2007;21(1):46-54.

17. Reissmann DR, John MT, Schierz O, Wassell RW. Functional and psychosocial impact related to specific temporomandibular disorder diagnoses. J Dent. 2007;35(8):643-50.

18. Yunus MB. Fibromyalgia and overlapping disorders: the unifying concept of central sensitivity syndromes. Semin Arthritis Rheum. 2007;36(6):339-56.

19. Wolfe F, Smythe HA, Yunus MB, Bennett RM, Bombardier C, Goldenberg DL, et al. The American College of Rheumatology 1990 Criteria for the Classification of Fibromyalgia. Report of the Multicenter Criteria Committee. Arthritis Rheum. 1990;33(2):160-72.

20. Pereira Júnior FJ, Favilla EE, Dworkin S, et al. Critérios de diagnóstico para pesquisa das disfunçóes temporomandibulares (RDC/TMD). Tradução oficial para a língua portuguesa. J Bras Clin Odontol Integr. 2004;8(47):384-95.

21. Dworkin SF, LeResche L. Research diagnostic criteria for temporomandibular disorders: review criteria, examinations and specifications, critique. J Craniomandib Disord. 1992;6(4):301-55.

22. Marbach JJ. Is myofascial face pain a regional expression of fibromyalgia? J Musc Pain. 1995;3(2):93-7.

23. Siqueira JTT. Disfunção temporomandibular: classificação e abordagem clínica. In: Siqueira JTT, Teixeira MJ (eds.). Dor orofacial: diagnóstico, terapêutica e qualidade de vida. Curitiba: Maio; 2001. 373-404p.

24. Clauw DJ, Arnold LM, McCarberg BH; Fibro Collaborative. The science of fibromyalgia. Mayo Clin Proc. 2011;86(9):907-11

25. Gracely RH, Petzke F, Wolf JM, Clauw DJ. Functional magnetic resonance imag ing evidence of augmented pain processing in fibromyalgia. Arthritis Rheum. 2002;46(5):1333-43.

26. Nebel MB, Gracely RH. Neuroimaging of fibromyalgia. Rheum Dis Clin North Am. 2009;35(2):313-27.

27. García-Moya EJ, Montiel-Company JM, Almerich-Silla JM. Case-control study of craniomandibular disorders in patients with fibromyalgia. J Clin Exp Dent. 2015;1;7(2):293-8 
28. Flores-Mir C, Nebbe B, Heo G, Major PW. Longitudinal study of temporomandibular joint disc status and craniofacial growth. Am J Orthod Dentofacial Orthop, 2006;130(3):324-30.

29. Cuccia A, Caradonna C. The relationship between the stomatognathic system and body posture. Clinics. 2009;64(1):61-6.

30. Pimentel MJ, Gui MS, Martins de Aquino LM, Rizzatti-Barbosa CM. Features of temporomandibular disorders in fibromyalgia syndrome. J Cranio. 2013;31(1):40-5.

31. Murphy MK, MacBarb RF, Wong ME, Athanasiou KA. Temporomandibular disorders: a review of etiology, clinical management, and tissue engineering strategies. Int J Oral Maxillofac Implants. 2013;28(6):e393-414.
32. Urban VM, Neppelenbroek KH, Pavan S, Alencar Júnior FG, Jorge JH, Almilhatti HJ. Associação entre otalgia, zumbido, vertigem e hipoacusia com desordens temporomandibulares. Rev Gaucha Odontol. 2009;57(1):107-15.

33. Silveira AM, Feltrin PP, Zanetti RV, Mautoni MC. Prevalência de portadores de DTM em pacientes avaliados no setor de otorrinolaringologia. Rev Bras Otorrinolaringol. 2007:73(4):528-32.

34. Bonjardim LR, Gavião MB, Pereira LJ, Castelo PM. Bite force determination in adolescents with and without temporomandibular dysfunction. J Oral Rehabil. 2005;32(8):577-83 